\title{
Feeding Ecology and Stranding Mechanisms in Two Lanternfishes, Hygophum benoiti and Myctophum punctatum
}

\author{
B. Scotto di Carlo ${ }^{1}$, G. Costanzo ${ }^{2}$, E. Fresi ${ }^{1}$, L. Guglielmo ${ }^{2}$ and A. Ianora ${ }^{1}$ \\ ${ }^{1}$ Stazione Zoologica di Napoli, I-80121 Napoli, Italy \\ ${ }^{2}$ Istituto di Idrobiologia e Piscicultura, University of Messina, Via dei Verdi 75, I-98100 Messina, Italy
}

\begin{abstract}
The feeding ecology of 2 vertically migrating midwater fishes - Hygophum benoiti and Myctophum punctatum - found stranded along the shores of the Straits of Messina was studied in order to reconstruct the ecological mechanisms involved in their stranding processes. Diet analyses revealed that both fishes fed mostly on copepods and euphausiids but also on a variety of other food items. Ontogenetic changes in the diet indicated that size selection determined prey choice in all stages in the life cycle of $H$. benoiti. M. punctatum, on the other hand, became opportunistic with age, adding new components to the diet without excluding prey items eaten by smaller individuals. At the species level, prey choice involved selective feeding on more visible prey items such as bioluminescent copepods. The prey population primarily included surface and migrating sub-surface species. Knowledge of prey vertical distribution patterns in the Mediterranean Sea suggests active feeding by both predators in surface waters at night. The absence of deep water non-migrating elements in the diet implies that the current hypothesis of passive transport of species due to surfacing deep water masses in the Straits may not hold true for all stranded organisms. Alternative stranding mechanisms involving active trophic migrations are proposed for midwater species known to undergo strong diel vertical movements.
\end{abstract}

\section{INTRODUCTION}

A most peculiar biological feature of the Straits of Messina, between Sicily and the Italian mainland, is the shore stranding of deep-water marine organisms. In the past this phenomenon attracted much attention from ecologists, yet to date little information is available on the physical and biological mechanisms involved in these strandings. One of the few detailed papers on this argument (Mazzarelli, 1909) consists of a list of species, including their time of stranding, over a period of $2 \mathrm{yr}$. Only recently has this list been incremented to include midwater fishes (Genovese et al., 1971) and pelagic and benthic crustaceans (Guglielmo et al., 1973).

The main cause in the stranding of midwater organisms is considered to be the complex hydrological regime (Vercelli, 1925; Defant, 1961), where surfacing deep-water masses in the Straits are thought literally to 'drag many deep-water organisms from their normal habitat' (Marshall, 1954). Subsequently, opposing tidal currents and favorable wind conditions, in particular
SE Sirocco winds, result in strandings along the coast. Little importance was credited to active migrations by midwater organisms to surface waters, although Mazzarelli (1909) hypothesized that passive transport to the surface may be facilitated by vertical migrations related to reproductive cycles, and Berdar et al. (1979) suggested that diel migrations may play an important role in this phenomenon.

To test the passive transport hypothesis we have undertaken a detailed study of the feeding ecology of the 2 most abundant midwater fishes to be washed ashore in this area, Hygophum benoiti (Cocco) and Myctophum punctatum Rafinesque. Both these myctophids are ranking midwater Mediterranean species, having day-depth distributions from 100 to $1000 \mathrm{~m}$ and maximum concentrations at $700-1000 \mathrm{~m}$. They undergo marked diel vertical migrations reaching the surface layers at night (Goodyear et al., 1972). If in the Straits of Messina these 2 species feed at the surface, and if such trophic migrations are facilitated by upwelling waters, one would expect to find a mixed population in their stomach which includes deep- 
water, non-migrating elements. A prey population consisting exclusively of typical surface-water species would disprove the passive transport hypothesis and encourage alternative explanations as to what mechanisms are involved in stranding processes.

\section{MATERIAL AND METHODS}

The specimens were collected by the Hydrobiology Department of the University of Messina. They included 145 individuals of Hygophum benoiti and 110 of Myctophum punctatum, sampled along the shores of the Straits of Messina near Faro, Ganzirri and S. Francesco (Fig. 1.). Beached material was collected early in the morning following strong onshore winds, in par-

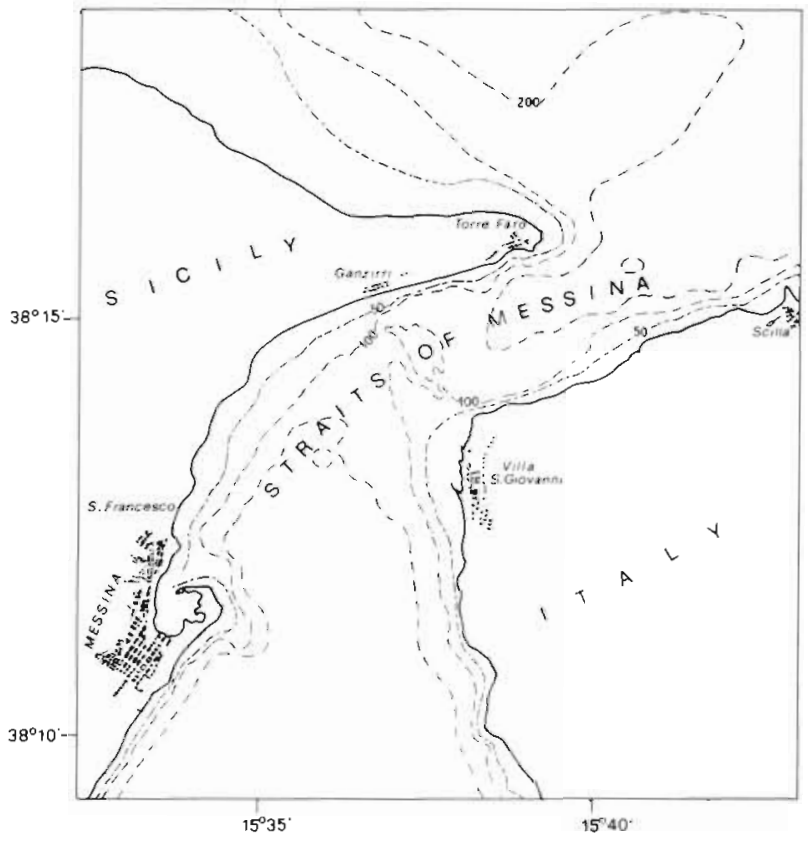

Fig. 1. Straits of Messina showing sampling sites

ticular SE (Sirocco) winds. Freshly stranded individuals were undamaged and some still alive. All $H$ benoiti were collected from March to June and August to December 1972; $M$. punctatum were collected from March to June and August to January 1972 to 1978. All specimens were measured to the nearest millimeter standard length (SL), separated according to sex; when possible, stomach contents were identified to species level. Size of individual prey was determined from intact specimens sampled in the Straits and adjacent areas. Biomass values were then calculated by assigning an average wet weight value to each prey item according to the method of Shmeleva (1965).

A multivariate analysis technique known as ' $R Q$ ' analysis (Hathaway, 1971) or Reciprocal Averaging
(Hill, 1973) was performed on all data. This technique, as well as others such as Factor Analysis of Correspondences (Benzecri, 1980), was particularly useful in the 'ordination of ecological systems' (Orloci, 1975), producing models in which the $R^{n}$ space of $n$ observations and the $R^{m}$ space of $m$ variables were isomorphic thus giving observations and variable points which could be projected on the same factorial space. Proximities between variable and observation points reflected reciprocal relationships. The significance of the models obtained with this technique was tested by a method proposed by Frontier (1974): a factor was considered significant when it explained more variance than it predicted by MacArthur's (1960) 'broken stick model'. Diversity of species and/or taxa ( $\left.\mathrm{H}^{\prime}\right)$ was calculated by means of the Shannon-Weaver formula, along with theoretical maxima-minima and redundancy (Patten, 1962). All calculations were perfomed on an Olivetti P 6060 minicomputer and are based on original programs and those adapted from Orloci (1975)

\section{RESULTS}

\section{Hygophum benoiti (Cocco, 1838)}

Hygophum benoiti was found stranded throughout the year in the Straits of Messina. Table 1 shows the stranding frequency recorded during the course of the present investigation. The largest number of stranded specimens occurred in autumn and winter. Males stranded more frequently than females $\left(X^{2}=15.5588\right.$; 135 d.o.f.; $p<.005)$ in all months except October. Nine of the 145 individuals could not be identified to sex.

Most of the specimens examined were adults (>40 mm) or subadults (20 to $40 \mathrm{~mm}$ ). Body length ranged from 21 to $60 \mathrm{~mm}$ with an annual mean of $44.11 \mathrm{~mm}$ ( $\mathrm{SD}=8.964)$. No significant difference was found between the mean annual length of males and females. The length-frequency distribution throughout the year is shown in Fig. 2. Mean body length steadily increased from early spring to late summer and decreased from October onwards. A minimum occurred in December when the population seemed to be entirely renewed. Reproduction probably reached a peak between April and September with early recruits appearing in October-November (Fig. 2a)

Of the 145 specimens sampled, 131 had full or partially full stomachs while the remaining 14 were empty. The complete faunistic spectrum for all seasons included 99 taxa (77 identified to the species level) belonging to 7 major groups as listed in Table 2 . Copepods and euphausiids (mainly juveniles) were dominant food items, representing $88.2 \%$ and $9.0 \%$ 
Table 1. Hygophum benoiti and Myctophum punctatum. Stranding frequency

\begin{tabular}{|c|c|c|c|c|c|c|c|c|c|c|c|}
\hline & Jan & Mar & Apr & May & Jun & Aug & Sep & Oct & Nov & Dec & Total \\
\hline \multicolumn{12}{|c|}{ H. benoiti } \\
\hline$\delta 8$ & - & 29 & 6 & 8 & 3 & 2 & 9 & 12 & 2 & 20 & 91 \\
\hline $९$ & - & 15 & 0 & 4 & 0 & 0 & 0 & 18 & 1 & 8 & 45 \\
\hline Total & - & 44 & 6 & 12 & 3 & 2 & 9 & 30 & 3 & 28 & 136 \\
\hline \multicolumn{12}{|c|}{ M. punctatum } \\
\hline 88 & 3 & 6 & 2 & 1 & 3 & 2 & 6 & 0 & 7 & 8 & 38 \\
\hline 99 & 1 & 10 & 1 & 1 & 2 & 4 & 0 & 40 & 5 & 2 & 66 \\
\hline Total & 4 & 16 & 3 & 2 & 5 & 6 & 6 & 40 & 12 & 10 & 104 \\
\hline
\end{tabular}

Table 2. Hygophum benoiti (H) and Myctophum punctatum (M). Principal prey taxa in the diet

\begin{tabular}{|c|c|c|c|c|c|c|c|c|}
\hline \multirow[t]{2}{*}{ Prey taxa } & \multicolumn{2}{|c|}{ No. species } & \multicolumn{2}{|c|}{ Prey items } & \multicolumn{2}{|c|}{$\%$ No. } & \multicolumn{2}{|c|}{$\%$ wet weight } \\
\hline & $\mathrm{H}$ & $M$ & $\mathrm{H}$ & M & $\mathrm{H}$ & $M$ & $\mathrm{H}$ & M \\
\hline Copepods & 57 & 70 & 3,089 & 5,711 & 88.2 & 82.5 & 27.3 & 40.3 \\
\hline Euphausiids & 4 & 8 & 318 & 302 & 9.0 & 4.3 & 71.3 & 54.0 \\
\hline Amphipods & 7 & 25 & 23 & 128 & 0.7 & 1.9 & 0.6 & 2.5 \\
\hline Mysiids & 4 & 4 & 11 & 9 & 0.3 & 0.1 & 0.2 & 0.1 \\
\hline Ostracods & 2 & 2 & 13 & 15 & 0.4 & 0.2 & 0.1 & 0.1 \\
\hline Chaetognaths & - & - & 24 & 172 & 0.7 & 2.5 & 0.5 & 2.7 \\
\hline Appendicularians & - & - & 1 & 400 & - & 5.8 & - & 0.3 \\
\hline Others & 3 & 11 & 25 & 190 & 0.7 & 2.7 & - & - \\
\hline
\end{tabular}
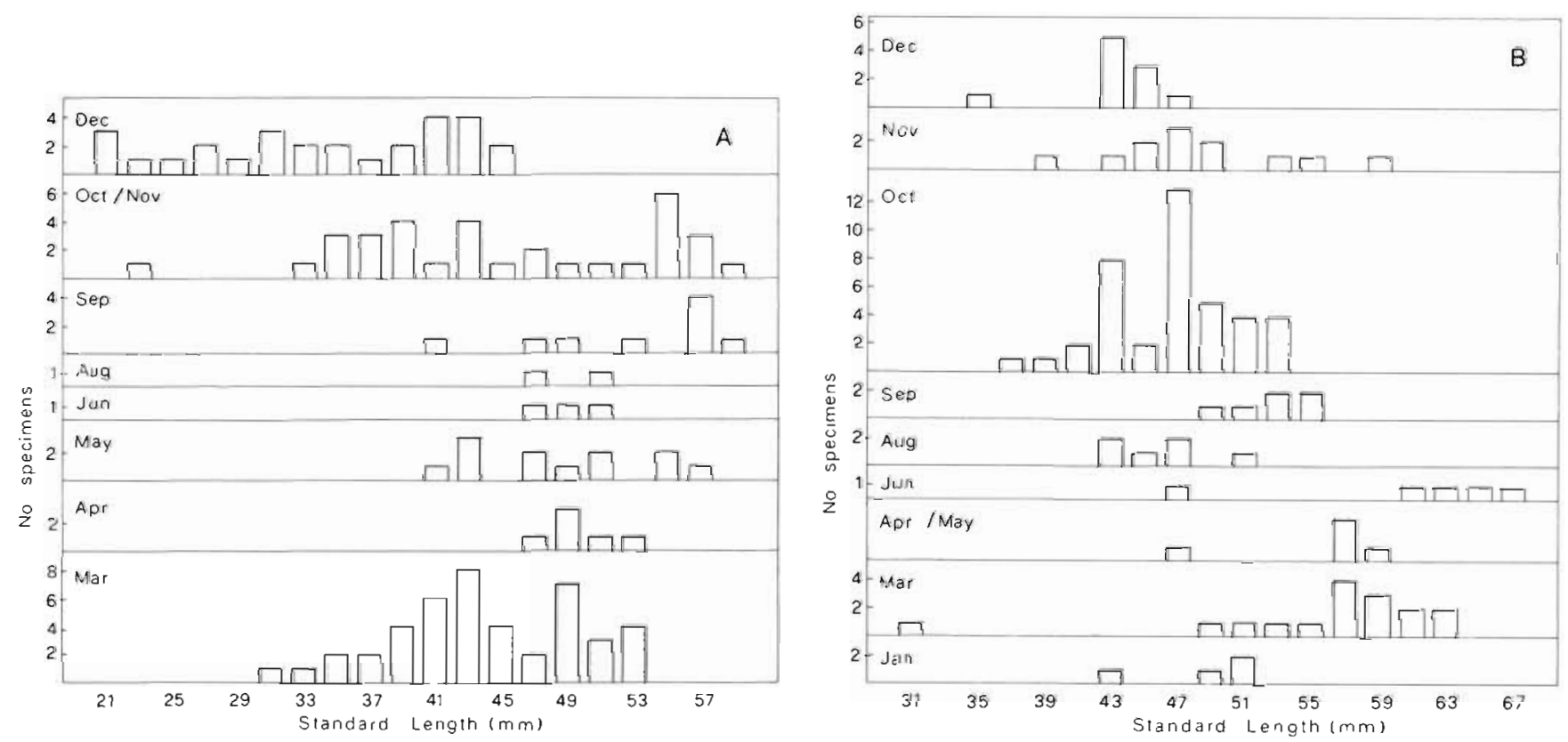

Fig. 2. Hygophum benoiti (A) and Myctophum punctatum (B). Annual size distribution (SL) of stranded specimens 
respectively of the total prey population as individuals and $27.3 \%$ and $71.3 \%$ respectively as biomass. The remaining taxonomic groups represented an insignificant fraction of the overall diet.

A species list of the stomach contents was compiled by pooling number of prey items for all seasons (Table 3). The list included 57 copepod, 4 euphausiid, 8 amphipod, 2 ostracod, 4 mysiid, 3 pteropod and 1 thaliacean species. Included were also several taxonomic groups such as chaetognaths, appendicularians, decapod and fish larvae which were not identified to the species level. The most dominant copepods occurring annually were species of the genus Pleuromamma (mainly $P$. abdominalis and P. gracilis), Nannocalanus minor, Oncaea mediterranea, Euchaeta marina, Temora stylifera, Lucicutia flavicornis, Paracandacia simplex, Candacia aethiopica, Neocalanus gracilis and Euchaeta sp. which together represented $91.6 \%$ of the total number of identified copepods. Among the euphausiids, Euphausia krohnii and Meganyctiphanes norvegica were the 2 main species eaten.

On a seasonal basis (Table 4), Hygophum benoiti fed mostly on copepods (Pleuromamma sp., $P$. abdominalis, $P$. gracilis, Oncaea mediterranea and Nannocalanus minor) and some euphausiids in winter and spring, but fed almost exclusively on copepods in autumn. During summer, euphausiids were dominant food items, particularly Euphausia krohnii. A synoptic picture regarding seasonal trends in the entire population was also given by an $R Q$ analysis using the 7 major taxonomic groups (Table 2 ) as variables and 131 specimens as observations. The analysis was performed both on numerical abundances and biomass values. In the case of abundance values little information was obtained since the same weight was given to taxa having greatly different biomasses, i.e. an appendicularian or a copepod ranked in exactly the same way as a much larger euphausiid. The results of $R Q$ analysis using biomass values is shown in Fig. 3a. The first two factors both significant explained $55.99 \%$ and $21.49 \%$, respectively, of the total variance. The correlation between prey taxa and fish specimen scores was 0.736 for $F 1$ and 0.456 for F2. The first axis opposed copepods with euphausiids. Amphipods, chaetognaths, appendicularians, mysiids and ostracods were located near the mid-point (O correlation). In the space of F2, mysiids were opposed to all other groups. Fish specimen-points were ordered linearly between the 2 extremes. The observations concentrated near the copepod pole represented $H$. benoiti specimens collected in all 4 seasons but, above all, those collected in winter and autumn. Summer observations were concentrated near the euphausiid pole. Several spring and some autumn observations were scattered all along $\mathrm{Fl}$ but in particular in the central portion of the diagram. Individuals of $H$. benoiti, having respectively small sizes (copepod pole) and large sizes (euphausiid pole) were grouped at the opposite poles of the diagram. This was demonstrated by the highly significant correlation value $(r=.539)$ between $F l$ and fish size. Prey biomass increased from the diagram's mid-point towards the opposite poles whereas diversity of prey items decreased towards both poles.

\section{Myctophum punctatum Rafinesque, 1810}

Myctophum punctatum in the Straits of Messina was found stranded throughout the year. The stranding frequency recorded during the present investigation appears in Table 1 . The annual sex ratio was in favor of females $\left(X^{2}=7.538 ; 103\right.$ d.o.f.; $\left.p<.005\right)$ due to the high number of stranded females in October. Two of the 106 specimens could not be identified to sex.

Most of the specimens were adults (>45 mm) or subadults (20 to $45 \mathrm{~mm}$ ). Body length ranged from 22 to $68 \mathrm{~mm}$ with an annual mean of $49.69 \mathrm{~mm}$ ( $\mathrm{SD}=7.119$ ). No significant difference was found between the mean annual length of males and females. The length-frequency distribution throughout the year is given in Fig. 2B. Mean body length increased from March to September and steadily decreased thereafter reaching a minimum in December. Smaller size classes appeared mostly from October onwards. These results suggest that reproduction reached a peak during spring and early summer.

Of the 106 specimens sampled, 101 had full or partially full stomachs and 5 were empty. The complete faunistic spectrum for all seasons included 152 taxa (125 identified to the species level) belonging to 7 major groups as listed in Table 2. Copepods and euphausiids (mainly juveniles) were the dominant food items comprising $82.5 \%$ and $4.3 \%$ respectively of the total prey population in terms of individuals and $40.3 \%$ and $54.0 \%$ respectively in terms of biomass. Of the remaining species, appendicularians and chaetognaths contributed respectively $5.7 \%$ and $2.5 \%$ of the total number of prey individuals.

A species list of the stomach contents for Myctophum punctatum is given in Table 5 . The list included 71 copepod, 8 euphausiid, 28 amphipod, 3 ostracod, 4 mysiid, 5 pteropod, 3 polychaete, 1 thaliacean, 1 fish and 1 isopod species. The list also included other taxonomic groups such as heteropods, chaetognaths, appendicularians, nematodes, hydromedusae, decapod and cirripede larvae which were not indentified to the species level. Several of the species recorded were benthic or bentho-planktonic. In particular, 
Table 3. Hygophum benoiti. List of prey species found in 145 specimens

\begin{tabular}{|c|c|c|c|c|c|}
\hline Food category & Total & Food category & Total & Food category & Total \\
\hline Copepods & & & & Ostracods & \\
\hline Calanus helgolandicus & 2 & Paracandacia bispinosa & 1 & Conchoecia haddoni & 3 \\
\hline C. tenuicornis & 1 & P. simplex & 40 & C.obtusata & 3 \\
\hline Nannocalanus minor & 198 & Candacia spp. & 11 & Conchoecia spp. & 3 \\
\hline Neocalanus gracilis & 32 & Oncaea conifera & 5 & Unidentified & 4 \\
\hline Calanus spp. & 18 & O. media & 10 & & \\
\hline Eucalanus monachus & 3 & O. mediterranea & 125 & Mysiids & \\
\hline Paracalanus parvus & 1 & O. venusta & 1 & Lophogaster typicus & 3 \\
\hline Calocalanus contractus & 1 & Oncaea spp. & 3 & Gastrosaccus lobatus & 1 \\
\hline C. pavo & 1 & Lubbockia squillimana & 2 & G. sanctus & 1 \\
\hline Clausocalanus arcuicornis & 17 & Sapphirina auronitens & 1 & Gastrosaccus sp. & 1 \\
\hline C. jobei & 1 & S. gemma & 1 & Anchialina agilis & 2 \\
\hline C. lividus & 8 & Copilia mediterranea & 1 & Unidentified & 3 \\
\hline C. mastigophorus & 4 & C. vitrea & 1 & & \\
\hline C. parapergens & 11 & Corycaeus clausi & 9 & Pteropods & \\
\hline C. pergens & 1 & C. flaccus & 3 & Limacina inflata & 1 \\
\hline Clausocalanus spp. & 11 & C. furcifer & 1 & L. trochiformis & 4 \\
\hline Euaetideus giesbrechti & 3 & C. giesbrechti & 1 & Limacina sp. & 1 \\
\hline Chiridius poppei & 1 & C. rostrata & 1 & Creseis virgula & 3 \\
\hline Euchirella messinensis & 12 & c. typicus & 3 & Creseis $\mathrm{sp}$ & 1 \\
\hline Euchaeta acuta & 6 & Unidentified & 422 & Unidentified & 6 \\
\hline E. hebes & 2 & & & & \\
\hline E. marina & 113 & Euphausiids & & Polychaetes & \\
\hline Euchaeta spp. & 38 & Euphausia krohnii & 129 & Unidentified fragments & 1 \\
\hline Scolecithrix bradyi & 1 & Euphausia spp. & 6 & & \\
\hline S. danae & 1 & Meganyctiphanes norvegica & 113 & Chaetognaths & \\
\hline Scolecithricella dentata & 3 & Nematoscelis megalops & 7 & Sagitta sp. & 24 \\
\hline Centropages typicus & 3 & Nematoscelis sp. & 1 & & \\
\hline C. violaceus & 3 & Stylocheiron longicorne & 1 & Thaliaceans & \\
\hline Temora stylifera & 87 & Stylocheironsp. & 1 & Thalia democratica & 1 \\
\hline Pleuromamma abdominalis & 424 & Unidentified & 41 & & \\
\hline P. borealis & 2 & Larvae & 19 & Appendicularians & \\
\hline P. gracilis & 178 & & & Oikopleura sp. & 1 \\
\hline P. piseki & 8 & Hyperid amphipods & & & \\
\hline P. robusta & 1 & Phronima atlantica & 1 & Fishes & \\
\hline Pleuromamma spp. & 1128 & Phronimella elongata & 2 & Cyclotonesp. & 1 \\
\hline Lucicutia flavicornis & 45 & Lestrigonus schizogeneios & 4 & & \\
\hline L. gemina & 10 & Lestrigonus spp. & 4 & Others & \\
\hline Heterorhabdus abyssalis & 1 & Phrosina semilunata & 3 & Decapod larvae & 5 \\
\hline H. papilliger & 4 & Primno macropa & 1 & Cirripede larvae & 1 \\
\hline Candacia aethiopica & 34 & Tetrathyrus forcipatus & 1 & & \\
\hline C. armata & 9 & Brachyscelus crusculum & 3 & & \\
\hline C. bipinnata & 3 & & & & \\
\hline C. giesbrechti & 2 & Gammariid amphipods & & & \\
\hline C. longimana & 11 & Unidentified & 4 & & \\
\hline
\end{tabular}

amphipods such as Gammarus olivii, Dexamine spp., Apherusa mediterranea; the mysiid Siriella jaltensis; isopods of the genus Euridice; ostracods of the genus Philomedes; and nematodes are strictly benthic or make only brief appearances in the plankton, especially at night (e.g. Euridice and Dexamine).

The most dominant copepods occurring annually were Nannocalanus minor, Temora stylifera, Pleuromamma sp., P. abdominalis, $P$. gracilis, Euchaeta marina, Euchirella messinensis, Paracandacia simplex, Neocalanus gracilis, Clausocalanus lividus, C. parapergens, Lucicutia flavicornis which together represented $88.0 \%$ of the total number of identified copepods. Among the euphausiids, Meganyctiphanes norvegica and Euphausia krohnii were the 2 main species eaten.

On a seasonal basis (Table 6), Myctophum punctatum fed primarily on copepods, showing no definite dominance of food items, except for summer when Nannocalanus minor, Temora stylifera, Euchaeta marina and Pleuromammasp. were the dominant prey. Euphausiids were important in spring (namely 
Table 4. Hygophum benoiti. Seasonal occurrence of more abundant ( $>1 \%$ ) prey species in the diet (mean no. stomach ${ }^{-1}$ )

\begin{tabular}{|c|c|c|c|c|}
\hline Prey & Winter & Spring & Summer & Autumn \\
\hline \multicolumn{5}{|l|}{ Copepods } \\
\hline Pleuromamma sp. & 10.39 & 22.23 & 0.36 & 2.38 \\
\hline Pleuromamma abdominalis & 3.02 & 5.59 & 2.73 & 2.00 \\
\hline Nannocalanus minor & 1.93 & 0.59 & 0.18 & 1.42 \\
\hline Pleuromamma gracilis & 0.85 & 1.91 & 0.18 & 1.44 \\
\hline Oncaea mediterranea & 2.59 & 0.14 & - & 0.05 \\
\hline Euchaeta marina & 0.28 & 0.41 & - & 1.38 \\
\hline Temora stylifera & 0.09 & 0.23 & 0.36 & 1.12 \\
\hline Lucicutia flavicornis & 0.20 & - & - & 0.55 \\
\hline Paracandacia simplex & 0.17 & 0.09 & 0.09 & 0.44 \\
\hline Euchaeta sp. & 0.22 & 0.45 & 0.36 & 0.21 \\
\hline Neocalanus gracilis & 0.24 & 0.18 & - & 0.26 \\
\hline Candacia aethiopica & 0.02 & - & 0.09 & 0.45 \\
\hline Unidentified & 21.67 & 33.18 & 5.00 & 13.38 \\
\hline \multicolumn{5}{|l|}{ Euphausiids } \\
\hline Meganyctiphanes norvegica & 2.22 & 0.27 & 0.45 & - \\
\hline Euphausia krohnii & 0.20 & 1.27 & 5.00 & 0.56 \\
\hline Unidentified & 2.52 & 1.55 & 5.73 & 0.68 \\
\hline
\end{tabular}
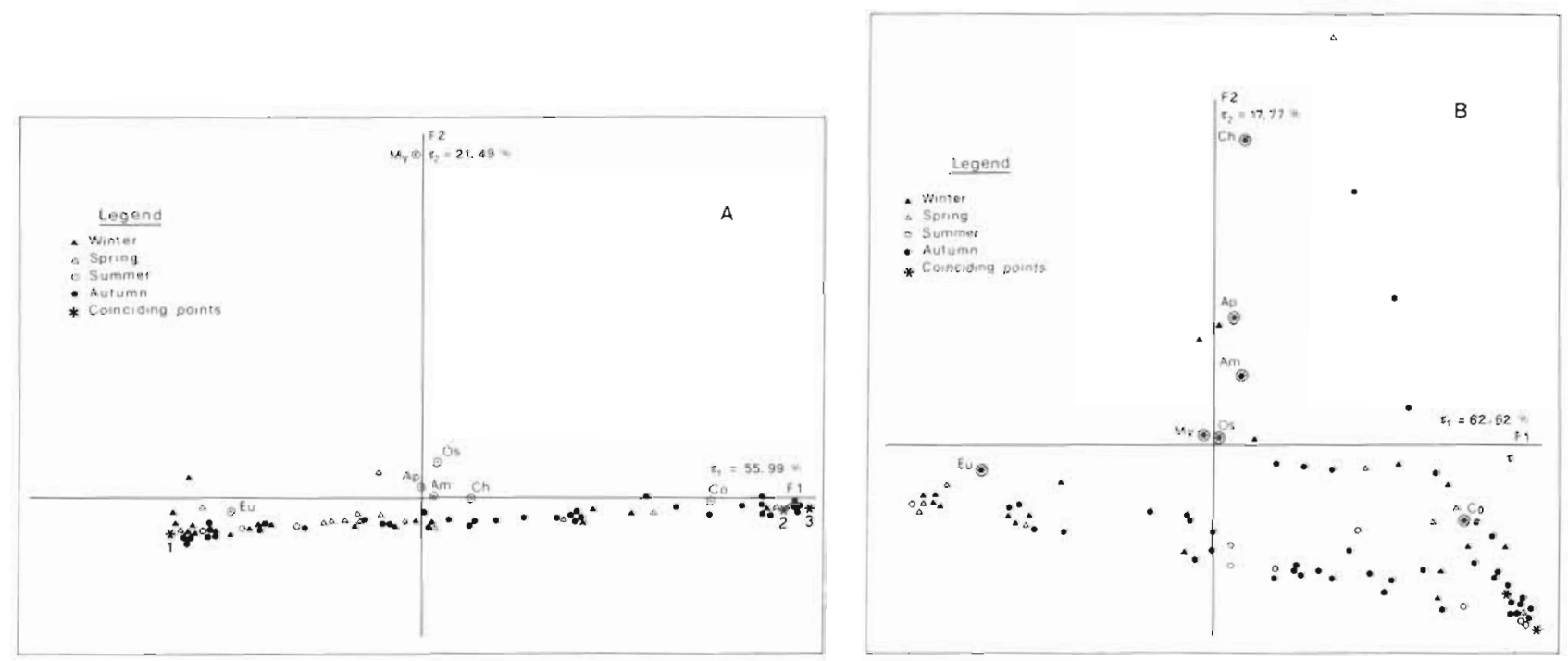

Fig. 3. RQ Analysis: Ordination model in the plane of the first two factors (F1 and F2), showing seasonal trends in diet composition of (A) Hygophum benoiti and (B) Myctophum punctatum and biomass values of various taxonomic groups ( $\tau=$ percentage of variance). Prey taxa: Co copepods, Eu euphausiids, Ap appendicularians, Am amphipods, Os ostracods, Ch chaetognaths, My mysids. Coinciding points for $H$. benoiti include: Point $1{ }^{*}=7$ winter, 7 summer and 5 autumn observations; Point $2^{*}=3$ winter and 2 autumn observations; Point $3^{*}=11$ winter, 7 spring and 17 autumn observations, and for M. punctatum: 3 winter, 1 spring, 4 summer and 10 autumn observations

Euphausia krohnil and especially in winter (Meganyctiphanes norvegica). Benthoplankters occurred only sporadically and did not show any apparent seasonal trends in the diet. Seasonal trends in the entire population were also analyzed by the $R Q$ method using the 7 major taxonomic groups as variables and the 101 specimens as observations. The analysis was performed on both numerical abundances and biomass values. Results obtained from abundance values gave little information as compared to those obtained from biomass values (for the same reason as for Hygophum benoitI). Therefore only these latter results are discussed. Fig. $3 \mathrm{~B}$ shows the ordination model in the plane of the first two factors that explained respectively $62.62 \%$ and $17.77 \%$ of the total variance, both being significant. The correlation of the 
Table 5. Myctophum punctatum. List of prey species found in 106 specimens

\begin{tabular}{|c|c|c|c|c|c|}
\hline Food category & Total & Food category & Total & Food category & Total \\
\hline Copepods & & & & Ostracods & \\
\hline Calanus helgolandicus & 14 & O. venusta & 2 & Conchoecia haddoni & 2 \\
\hline C. tenuicornis & 42 & Pachos punctatum & 1 & Conchoeciasp. & 1 \\
\hline Nannocalanus minor & 1144 & Sapphirina auronitens & 3 & Philomedes globosus & 1 \\
\hline Neocalanus gracilis & 93 & S. nigromaculata & 1 & Philomedes sp. & 1 \\
\hline Calanus spp. & 9 & S. opalina & 3 & Cylindroleberis spp. & 8 \\
\hline Eucalanus attenuatus & 1 & Copilia vitrea & 2 & Unidentified & 2 \\
\hline E. elongatus & 5 & Corycaeus clausi & 38 & & \\
\hline E. monachus & 4 & C. flaccus & 26 & Mysiids & \\
\hline Paracalanus nanus & 2 & C. furcifer & 4 & Siriella clausi & 2 \\
\hline Calocalanus pavo & 25 & C. ovalis & 2 & S. jaltensis & 1 \\
\hline Mecynocera clausi & 1 & C. rostrata & 11 & S. norvegica & 2 \\
\hline Clausocalanus arcuicornis & 38 & C. typicus & 15 & Siriella sp. & 1 \\
\hline C. furcatus & 4 & Monstrilla sp. & 1 & Anchialina agilis & 3 \\
\hline C. jobei & 7 & Unidentified & 990 & & \\
\hline C. lividus & 61 & & & Pteropods & \\
\hline C. mastigophorus & 8 & Euphausids & & Limacina inflata & 6 \\
\hline C. parapergens & 57 & Euphausia brevis & 2 & Limacina spp. & 5 \\
\hline C. paululus & 1 & E. hemigibba & 3 & Creseis acicula & 17 \\
\hline C. pergens & 8 & E. krohnii & 47 & C. virgula & 1 \\
\hline Clausocalanus spp. & 5 & Meganyctiphanes norvegica & 180 & Creseis spp. & 16 \\
\hline Ctenocalanus vanus & 1 & Nematoscelis atlantica & 1 & Hyalocylis striata & 1 \\
\hline Aetideus armatus & 2 & N. megalops & 20 & Cavolinia inflexa & 1 \\
\hline Euaetideus giesbrechti & 13 & Stylocheiron longicorne & 5 & Cavolinia sp. & 1 \\
\hline Chiridius poppei & 1 & Thysanopoda eaqualis & 1 & Unidentified & 3 \\
\hline Euchirella messinensis & 238 & Unidentified & 3 & & \\
\hline Euchaeta acuta & 13 & Larvae & 40 & Heteropods & \\
\hline E. marina & 242 & & & Unidentified & 51 \\
\hline E. spinosa & 6 & Amphipods & & & \\
\hline Euchaeta spp. & 25 & Hyperiids & & Polychaetes & \\
\hline Scolecithricella abyssalis & 1 & Scina crassicornis & 1 & Vanadis cristallina & 1 \\
\hline S. dentata & 1 & Vibilia armata & 4 & Vanadis sp. & 2 \\
\hline Centropages kröyeri & 1 & $V$. cultripes & 2 & Callizona angelini & 4 \\
\hline C. typicus & 24 & Vibilia sp. & 1 & C. setosa & 1 \\
\hline C. violaceus & 19 & Phronima colletti & 2 & Unidentified fragments & 151 \\
\hline Temora stylifera & 890 & P. sedentaria & 3 & & \\
\hline Pleuromamma abdominalis & 400 & P. stebbingi & 3 & Chaetognaths & \\
\hline p. borealis & 1 & Phronimasp. & 1 & Sagitta spp. & 172 \\
\hline P. gracilis & 282 & Lestrigonus schizogeneios & 15 & & \\
\hline P. piseki & 1 & L. latissimus & 4 & Thaliaceans & \\
\hline P. rabusta & 15 & Hyperietta luzoni & 1 & Thalia democratica & 6 \\
\hline Pleuromamma spp. & 483 & H. stephenseni & 1 & Unidentified fragments & 258 \\
\hline Lucicutia clausi & 6 & Phronimopsis spinifera & 26 & & \\
\hline L. flavicornis & 65 & Phrosina semilunata & 4 & Appendicularians & \\
\hline L. gemina & 14 & Lycaea sp. & 1 & Oikopleura spp. & 400 \\
\hline Heterorhabdus abyssalis & 2 & Parascelus typhoides & 14 & & \\
\hline H. papilliger & 2 & Brachyscelus crusculum & 2 & Fishes & \\
\hline H. spinifrons & 2 & Simorhynchotus antennarius & 1 & Cyclotone braueri & 2 \\
\hline Haloptilus longicornis & 5 & Calamorhynchus pellucidus & 1 & Cyclotonesp. & 2 \\
\hline H. spiniceps & 2 & & & Larvae & 14 \\
\hline H. validus & 2 & Gammariids & & Eggs & 2 \\
\hline Arietellus setosus & 2 & Ampelisca diadema & 1 & & \\
\hline Candacia aethiopica & 1 & Bathyporeia pelagica & 1 & Isopods & \\
\hline C. armata & 2 & Urothoe marina & 3 & Eurydice inermis & 3 \\
\hline C. bipinnata & 2 & Urothoesp. & 2 & Eurydice sp. & 2 \\
\hline C. longimana & 14 & Pontocrates arenarius & 1 & & \\
\hline Paracandacia bispinosa & 12 & Melita sp. & 5 & Others & \\
\hline P. simplex & 200 & Gammarus olivii & 7 & Unidentified Nematodes & 3 \\
\hline Candaciasp. & 1 & Gammarus spp. & 5 & Hydromedusae & 1 \\
\hline Acartia clausi & 1 & Dexamine spiniventris & 1 & Decapod larvae & 42 \\
\hline Oithona setigera & 3 & D. spinosa & 4 & Cirripede larvae & 3 \\
\hline Oncaea conifera & 39 & D. thea & 5 & & \\
\hline Oncaea media & 13 & Apherusa mediterranea & 1 & & \\
\hline O. mediterranea & 34 & Unidentified & 5 & & \\
\hline
\end{tabular}


Table 6. Myctophum punctatum. Seasonal occurrence of more abundant ( $>1 \%$ ) prey species in the diet (mean no. stomach ${ }^{-1}$ )

\begin{tabular}{|c|c|c|c|c|}
\hline \multirow[b]{2}{*}{ Prey } & \multicolumn{4}{|c|}{ No. ind. stomach ${ }^{-1}$} \\
\hline & Winter & Spring & Summer & Autumn \\
\hline \multicolumn{5}{|l|}{ Copepods } \\
\hline Nannocalanus minor & 5.14 & 5.30 & 34.58 & 9.43 \\
\hline Temora stylifera & 0.24 & 0.50 & 31.25 & 7.39 \\
\hline Pleuromamma sp. & 1.29 & 6.10 & 7.75 & 4.51 \\
\hline Pleuromamma abdominalis & 3.19 & 5.60 & 1.33 & 3.90 \\
\hline Pleuromamma gracilis & 2.67 & 1.60 & 4.75 & 2.28 \\
\hline Euchaeta marina & 0.52 & - & 10.33 & 1.60 \\
\hline Euchirella messinensis & 0.29 & 0.20 & 0.08 & 3.42 \\
\hline Paracandacia simplex & 0.29 & 0.30 & 1.17 & 2.64 \\
\hline Neocalanus gracilis & 0.52 & 1.10 & 0.75 & 0.93 \\
\hline Lucicutia flavicornis & 0.10 & 0.10 & 0.17 & 0.90 \\
\hline Clausocalanus lividus & 1.43 & 0.10 & - & 0.45 \\
\hline Clausocalanus parapergens & 0.48 & 0.40 & 0.08 & 0.63 \\
\hline Unidentified & 22.05 & 23.10 & 94.25 & 44.19 \\
\hline \multicolumn{5}{|l|}{ Euphausiids } \\
\hline Meganyctiphanes norvegica & 8.24 & 0.50 & - & 0.03 \\
\hline Euphausia krohnii & 0.24 & 2.60 & 1.17 & 0.03 \\
\hline Unidentified & 8.86 & 3.20 & 1.17 & 0.31 \\
\hline
\end{tabular}

first set of variable and observation scores was 0.777 and the correlation of the second set was 0.414 . Fl opposed euphausiids with copepods while the other taxa were located near its mid-point. Little scattering of the variable-points was observed in the space of $F 2$, except for chaetognaths that were located at its positive pole. Observation-points were arranged along Fl in a quasi-linear fashion. The model did not indicate a clear seasonal trend though a number of winter observations were concentrated near the euphausiid pole. Regression analysis demonstrated that F1 was linearly and significantly correlated with prey biomass $(r=-.545)$, prey taxa number $(r=-399)$, prey diversity $(r=-.642)$ and fish size $(r=-.33)$.

An $R Q$ analysis was also performed on a copepod population of 70 species observed in both Hygophum benoiti and Myctophum punctatum of intermediate size $(40$ to $50 \mathrm{~mm})$ in all 4 seasons. This was done in order to avoid any bias due to fish size. Fig. 4 shows the ordination model in the plane of the first two factors. $H$. benoiti had a uniform diet as compared to the more mixed diet observed in $M$. punctatum. Two distinct seasonal trends were evident: both species fed on different prey populations in winter (and spring for $H$. benoiti) but their diet overlapped the rest of the year. Opposed 'feeding fields' (i.e. groups of species in opposite areas of the factorial space) were characterized by Nannocalanus minor, Clausocalanus parapergens, and $C$. lividus for $M$. punctatum in winter, and Pleuromamma gracilis, Pleuromamma sp. and Oncaea mediterranea for $H$. benoiti in this same period. Species characteristic of the common 'feeding field' (species common to both predators) were Pleuromamma gracilis, Neocalanus gracilis, Euchaeta marina, Lucicutia flavicornis, and Temora stylifera.

\section{DISCUSSION}

Diet analysis of stranded Hygophum benoiti and Myctophum punctatum revealed a number of general features on the feeding ecology of both fishes. Changes were generally observed in both size and taxonomic composition of the diet with age. The relationship between fish size and prey population parameters such as size, biomass and diversity - were analyzed and conceptual models derived from the results obtained using RQ analysis (Fig. 3). Fig. $5 \mathrm{~A}$ shows that $H$. benoiti had a polarized feeding behavior with respect to different prey size classes; small individuals tended to feed almost exclusively on copepods, whereas larger ones shifted toward an euphausiid. based diet. Prey diversity and biomass of other zooplankton taxa was maximum in intermediate size classes when $H$. benoiti fed on a larger proportion of intermediate-sized prey such as amphipods, mysiids and chaetognaths. This model implies not only a greater efficiency in capturing larger prey with increasing fish size but size selective feeding during all stages of the life cycle. $M$. punctatum, on the other hand, had a mixed diet during all stages of its development, except for small individuals that fed almost exclusively on copepods (Fig. 5 B). Though this trend was irregular, diversity and biomass of the prey items generally 


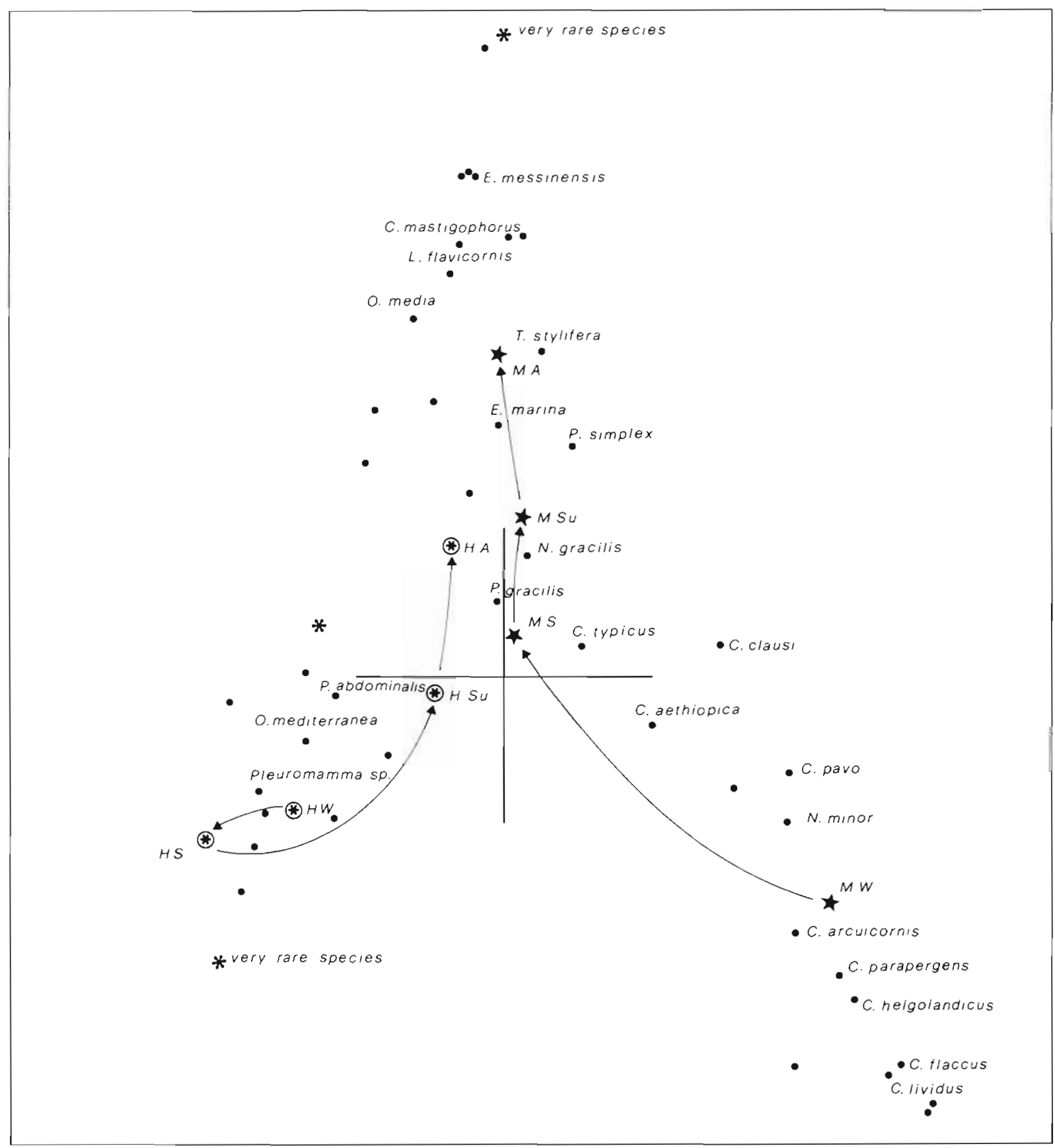

Fig. 4. RQ Analysis: Ordination model in the plane of the first two factors, showing seasonal trends in diet composition of the copepod prey population in internediate Hygophum benoiti and Myctophum punctatum size classes (40 to $50 \mathrm{~mm}$ ). Points: copepod species (only abundant species reported). H. benoiti winter HW; spring HS; summer HSu; autumn HA. $\star M$. punctatum winter $\mathrm{MW}_{\text {; }}$ spring $\mathrm{MS}_{\text {; }}$ summer $\mathrm{MSu}_{\text {i }}$ autumn $\mathrm{MA}$

increased with increasing fish size. This suggests that M. punctatum becomes a more opportunistic and efficient predator with age. Opportunistic feeding of this type, where larger individuals add components to their diets but do not exclude prey items eaten by smaller individuals, was also demonstrated for Stenobrachius leucopsarus and may represent the more common feeding strategy for midwater fishes (Collard, 1970; Tyler and Pearcy, 1975). M. punctatum was also the more active predator, utilizing a broader range of food items such as gastropods, thaliaceans and appendicularians which were almost absent in the diet of $H$. benoiti. Furthermore, $M$. punctatum fed on almost twice the number of individuals as compared to $H$. 


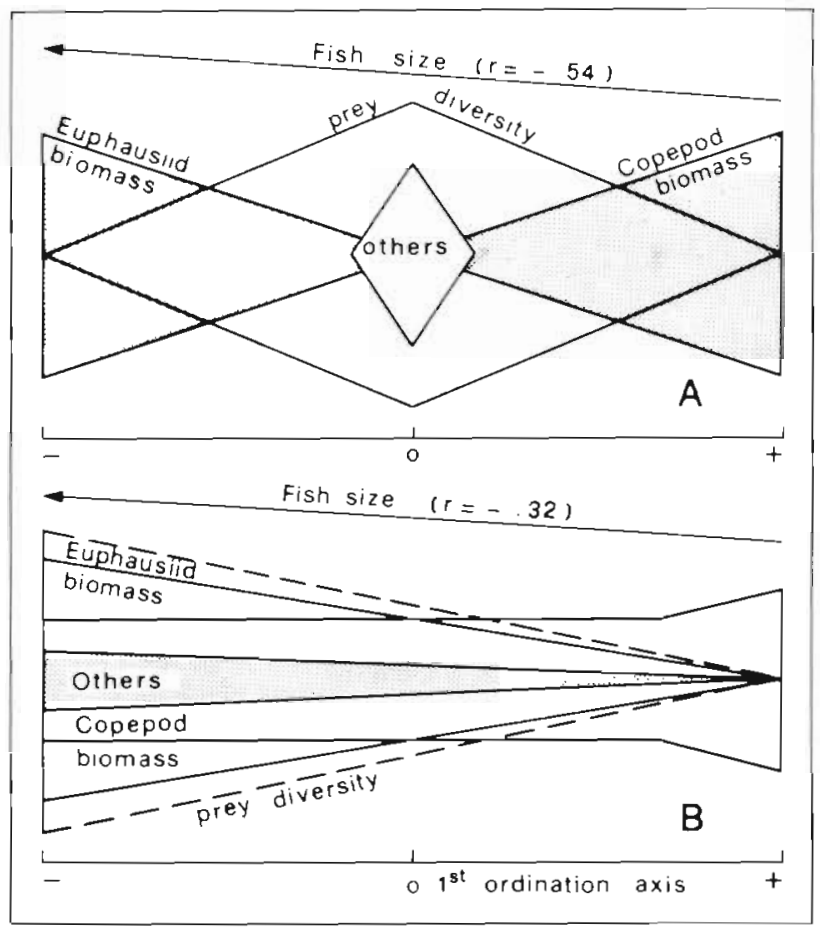

Fig. 5. Conceptual model of the relationship between fish size and prey size, biomass and diversity in (A) Hygophum benoiti and (B) Myctophum punctatum ( $\mathrm{t}=$ correlation coefficient between fish size and first axis of the ordination model)

benoiti (1.47 times more in terms of biomass). This may imply higher absolute energy requirements.

The data available on net zooplankton of the Straits of Messina, which includes day-night zooplankton sampled in various areas of the Straits at discrete levels from $500 \mathrm{~m}$ to the surface (own unpubl. data), provide evidence that the faunistic composition and vertical distribution of individual species are similar to those recorded for other Mediterranean waters such as the Tyrrhenian and Adriatic Seas (Hure and Scotto di Carlo, 1968, 1969a). Since the turbulence associated with upwelling may not affect the overall structure of the zooplankton community of the Straits, knowledge on prey distribution patterns can furnish valuable information on depth and time of feeding of the predators. The stomach contents of both Hygophum benoiti and Myctophum punctatum were heavily dominated by copepods and euphausiids. Abundant food items included typical surface species such as the copepods Nannocalanus minor, Temora stylifera and Euchaeta marina, and intermediate-water species that undergo strong diel migrations reaching the surface at night such as the copepods Pleuromamma gracilis and $P$. abdominalis and the euphausids Meganyctiphanes norvegica and Euphausia krohnii (Hure, 1961; Casanova-Soulier, 1968; Hure and Scotto di Carlo, 1969b). Few intermediate and no deep water nonmigrating species (i.e. species with day-night residence depths below $200 \mathrm{~m}$ ) were recorded in the stomach contents indicating that both $H$, benoiti and $M$. punctatum had fed in surface waters at night. Both fishes fed more or less on the same prey species (Tables 2 and 4) but surface species prevailed in $M$. punctatum whereas migrating intermediate-water species were more common in $H$. benoiti. This suggests that the 2 fishes probably fed at slightly different depth levels. That is, $M$. punctatum may have fed at the near surface and $H$. benoiti at a somewhat lower depth. Distinct 'feeding fields' were in fact demonstrated when an $\mathrm{RQ}$ analysis was performed on a homogeneous prey population (copepods) using only one predator size class (Fig. 4). Overlapping of the diet, however, occurred in summer and autumn reflecting low prey diversity in the surrounding waters at this time (see also Hure and Scotto di Carlo, 1968) and consequently a greater probability of capturing the same prey species.

Seasonal differences in the diet reflected predator size-distribution patterns and taxonomic composition of the prey population at the time of feeding. It follows that the relative abundance of larger prey items such as euphausiids occurred in winter in Myctophum punctatum and summer in Hygophum benoiti when both species respectively reached their maximum size. Feeding on the same food type in different periods of the year may reduce competition for available resources in these 2 cohabiting fishes. At the species level, however, changes in diet composition may simply reflect prey availability in different periods of the year. Species were in fact preyed upon by both predators in a larger proportion when they reached peak abundances in the surrounding waters (e.g. Temora stylifera and Euchaeta marina in summer and autumn; Oncaea mediterranea, Clausocalanus lividus and Meganyctiphanes norvegica in winter; Euphausia krohnii in spring and summer). Nevertheless, the species assemblage in the stomachs did not exactly reflect the zooplankton population at the time of feeding. Smali dominant copepods (about $1 \mathrm{~mm}$ ) such as Clausocalanus furcatus and Ctenocalanus vanus were rarely consumed. Excluding size selection due to gill raker spacing (Ebeling and Cailliet, 1974), this suggests visually oriented predation on appropriate size classes and probably stronger feeding pressure on more visible organisms (Confer et al., 1978). Preferential feeding on the genus Pleuromamma has been reported by several authors (Hopkins and Baird, 1973, 1977; Merrett and Roe, 1974; Clarke 1978, 1980; Baird and Hopkins, 1981). Our results suggest that selective feeding occurred not only on the genus Pleuromamma but on other bioluminescent copepods such as Nan- 
nocalanus minor and Neocalanus gracilis (Tett and Kelly, 1973) which were preyed upon in a larger proportion than their absolute abundance in surrounding waters. For these copepods the adaptive significance of bioluminescence therefore does not seem to involve predator avoidance mechanisms. Prey choice, however, may also involve aggregation or patchy distribution of food items as demonstrated by the presence of a monospecific and even monosexual prey population in the stomachs of several $H$. benoiti and $M$. punctatum (e.g. 119 male and 1 female specimens of the copepod $T$. stylifera were the only food items in $1 \mathrm{M}$. punctatum specimen).

Can the results obtained from stomach contents analyses give insight into the mechanisms involved in the shore stranding of these 2 species? Current opinion emphasizes physical factors, namely strong vertical currents in the Straits, as the main cause involved in the passive transport of midwater organisms to the surface and under favorable wind conditions these organisms are then washed ashore.

Though stranding frequency is maximum in autumn and winter when SE winds are stronger and more frequent, our results provide evidence that for $\mathrm{Hy}$ gophum benoiti and Myctophum punctatum, at least, physical factors may have a minor role in this phenomenon. This assumption is based on the facts that:

(1) Individuals below $21 \mathrm{~mm}$ for $H$. benoiti and $22 \mathrm{~mm}$ for $M$. punctatum were never found stranded. Excluding any bias in sampling smaller individuals, we can assume that juveniles do not strand. If the vertical passive transport hypothesis were to hold true, small size classes, less capable of actively opposing vertical currents, would be much more frequent in stranded material. The greater swimming capacity of larger individuals is demonstrated by the fact that they capture such large and fast-moving prey items as euphausiids.

(2) No everted stomachs were found in Hygophum benoiti or Myctophum punctatum. Stomach eversion from distended swim bladders is well known in midwater fishes when they undergo rapid decompression of the type implied by the vertical passive transport hypothesis

(3) Few empty stomachs were recorded (5 for $\mathrm{Myc}$ tophum punctatum and 14 for Hygophum benoiti) and the contents were generally poorly digested. Contents analyses revealed that only surface or sub-surface migrating elements had been eaten indicating that stranded fishes were feeding near the sea-surface. Should the vertical passive transport hypothesis hold true, one would expect to find deep water non-migrating zooplankters in the prey population, either fed upon in their normal habitat or in surface waters. There is no reason to believe that differential passive transport applies to predators and their prey.

The above considerations suggest that Hygophum benoiti and Myctophum punctatum are strong vertical migrators that feed on surface zooplankton communities. Such trophic migrations most probably occur at night when both fishes are known to reach the surface layers (Goodyear et al., 1972; Nafpaktitis et al., 1977). The diet composition strongly resembles a nocturnal zooplankton community in surface waters, consisting of both surface and migrating sub-surface species. It is worth noting, however, that while $H$. benoiti migrates only in open waters, $M$. punctatum may also intrude to near-shore environments as demonstrated by the presence in the stomach contents of benthoplankters inhabiting shallow, soft-bottom waters. Seemingly, trophic migrations involve only adult populations of both species. Differences in stranding frequency recorded for males and females may be due to differences in migrating behaviour.

Stranding of these lanternfishes probably occurs during or after feeding when fish are caught in surface eddies formed by opposing tidal currents and pushed ashore by onshore SE winds. The stranding mechanisms discussed above may not (and probably do not) necessarily apply to other stranded midwater organisms which include non-migrants such as fish species of the genus Cyclothone and weak migrants such as Argyropelecus hemigymnus. In conclusion, we believe that there is no univocal explanation of this phenomenon since each species will react differently to the same environmental stress, depending on the biology of the single species. Stomach contents analyses may, however, serve as a valuable tool in reconstructing the mechanisms involved in the stranding of these species.

Acknowledgements. The authors wish to thank Dr. Carmelo Tomas for helpful discussions and criticism of the manuscript. Thanks are also due to $G$. Princivalli for preparing the manuscript and M. Di Genova for inking the drawings.

\section{LITERATURE CITED}

Baird, R. C., Hopkins, T L. (1981). Trophodynamics of the fish Valenciennellus tripunctatus. II. Selectivity, grazing rates and resource utilization. Mar. Ecol. Prog. Ser. 5: 11-19

Benzecri, J. P. (1980), L'analyse des données, Vols. I, II, Dunod, Paris

Berdar, A., Costanzo, G., Guglielmo, L., Ianora, A., Scotto di Carlo, B. (1979). Some aspects on the feeding habits of two species of midwater fishes stranded along the shores of the Straits of Messina. Rapp. P.-v. Réun. Comm. int. Explor. scient. Mer Méditerr. 25/26: 209-210

Casanova-Soulier, B. (1968). Les euphausiacés de la Mediterranée. Comm. int. Explor. scient. Mer Méditerr. Mimeogr report, $1-62$

Clarke, T A. (1978). Diel feeding patterns of 16 species of 
mesopelagic fishes from Hawaiian waters. Fish. Bull U. S. 76: $495-513$

Clarke, T. A. (1980). Diets of fourteen species of vertically migrating mesopelagic fishes in Hawailan waters. Fish. Bull. U. S. 78: 619-640

Collard, S. B. (1970). Forage of some eastern Pacific midwater fishes. Copeia 2: 348-354

Confer, J. L., Howick, G. L., Corzette, M. H., Kramer, S. L., Fitzgibbon, S., Landesberg, R. (1978). Visual predation by planktivores. Oikos 31:27-37

Defant, A. (1961). Physical oceanography, Vols, I, II, Pergamon Press, Oxford

Ebeling, A. E., Cailliet, G. M. (1974). Mouth size and predator strategy in midwater fishes. Deep Sea Res. 21: 959-968

Frontier, S. (1974). Contribution à la connaissance dun écosystème néritique tropicale: étude descriptive et statistique du peuplement zooplanctonique de la région de Nosy-Bé (Madagascar). Thèse Doct., Université AixMarseille

Genovese, S., Berdar, A., Guglielmo, L. (1971). Spiaggiamenti di fauna abissale nello Stretto di Messina. Atti Soc. Peloritana 17: 331-370

Goodyear, R. H., Zahuranec, B. J., Pugh, W. L., Gibbs, R. H. Jr. (1972). Ecology and vertical distribution of Mediterranean midwater fishes. In: Mediterranean biological studies. Final report. Vol. 1. Smithsonian Institution, Washington, D. C., pp. 91-230

Guglielmo, L., Costanzo, G., Berdar, A. (1973). Ulteriore contributo alla conoscenza dei crostacei spiaggiati lungo il Littorale Messinese dello Stretto. Atti Soc. Peloritana 19: $129-156$

Hathaway, W H. (1971). Contingency-table analysis of rain forest vegetation. In: Patil, A., et al. (eds.) Statistical ecology. London: Pennsylvania State University Press, Pennsylvania, pp. 271-307

Hill, M. O. (1973). Reciprocal averaging: An eigenvector method of ordination. J. Ecol. 61: 237-249

Hopkins, T. L., Baird, R. C. (1973) Diet of the hatchetfish Sternoptyx diaphana. Mar. Biol. 21: 34-46

Hopkins, T. L., Baird, R. C. (1977). Aspects of the feeding ecology of oceanic midwater fishes. In: Andersen, N. R., Zahuranec, B. J. (eds.) Oceanic sound scattering prediction, Plenum Press, New York, pp. 325-360

Hure, J. (1961). Daily migration and seasonal vertical dis- tribution of zooplankton in the depths of the Adriatic. (In Serbo-Croation) Acta adriat. 9: 1-60

Hure, J., Scotto di Carlo, B. (1968), Comparazione tra lo zooplancton del Golfo di Napoli e dell'Adriatico meridionale presso Dubrovnik. I. Copepoda. Pubbl. Staz. zool. Napoli 36: 21-102

Hure, J., Scotto di Carlo, B. (1969a). Ripartizione quantitativa e distribuzione verticale dei Copepodi pelagici di profondità su una stazione nel mar Tirreno ed una nell' Adriatico meridionale. Pubbl. Staz. zool. Napoli 37: 51-83

Hure, J., Scotto di Carlo, B. (1969b). Diurnal vertical migration of some deep-water copepods in the Southern Adriatic (East Mediterranean). Pubbl. Staz. zool. Napoli 37: $581-598$

MacArthur, R. (1960). On the relative abundance of species. Am. Nat. 94: 25-36

Marshall, N. B. (1954), Aspects of deep sea biology, Hutchinson's Scientific and Technical Publications, London

Mazzarelli, G. (1909). Gli animali abissali e le correnti sottomarine dello Stretto di Messina. Riv. mens. Pesca Idrobiol. 11: 177-218

Merrett, N. R., Roe, H. S. J. (1974). Patterns and selectivity in the feeding of certain mesopelagic fishes. Mar. Biol. 28: $115-126$

Nafpaktitis, B. G., Backus, R. H., Craddock, J. E., Haedrich, R. L., Robison, B. H., Kamella, C. (1977). Family Myctophidae. In: Gibbs, R. H. (ed.) Fishes of the Western North Atlantic, Part 7. Mem. Sears Fun mar. Res. 1(7): 13-265

Orloci, L. (1975). Multivariate analysis in vegetation research, The W. Junk B. V Publ., The Hague

Patten, B. C. (1962). Species diversity in net plankton of Raritan Bay. J. mar. Res. 20:57-75

Shmeleva, A. A. (1965). Weight characteristics of the zooplankton of the Adriatic Sea. Bull. Inst. océanogr. Monaco 65: $1-24$

Tyler, H. R. Jr., Pearcy, W. G. (1975). The feeding habits of three species of lanternfishes (Family Myctophidae) off Oregon, USA. Mar Biol. 32: 7-11

Tett, P. B., Kelly, M. G. (1973). Marine bioluminescence Oceanogr. Mar. Biol. Rev. 11: 89-173

Verćelli, F. (1925). Crociere per lo studio dei fenomeni nello Stretto di Messina. Parte I. Il regime delle correnti e delle maree nello Stretto di Messina. Comm. Intern. del Mediterraneo, Venezia 